Plant Tissue Cult. \& Biotech. 27(1): 1-11, 2017 (June)

$\overline{\text { PTC\&B }}$

\title{
Elimination of Indian Citrus Ringspot Virus in Kinnow by Using Phytoproteins with Shoot-tip Grafting
}

\author{
Vikas Bishnoi*, Anshul Goyal and HN Verma ${ }^{1}$ \\ Department of Agriculture, Faculty of Sciences, Jagannath University, Jaipur-302033, \\ Rajasthan, India
}

Key words: Kinnow, Ringspot virus, Elimination, Shoot-tip grafting

\begin{abstract}
The combined beneficial effect of shoot-tip grafting with phytotherapy of different phytoproteins obtained from roots of Boerhaavia diffusa and leaves of Clerodendrum aculeatum to eliminate Indian citrus ringspot virus (ICRSV) from Kinnow is reported. The study also reports the effect of these phytoproteins on the growth and proliferation of Kinnow explants when nodal segments from infected mother plants (confirmed by RT-PCR) cultured in MS containing different concentrations of aqueous extracts of these individual phytoproteins. Shoot-tips from these nodal sprouts were grafted on Citrus jambhiri under in vitro condition. Phytoproteins from $C$. aculeatum were found utmost effective in respect of elimination of $50 \%$ virus followed by B. diffusa (40\%). In respect of promotion of growth and proliferation of nodal explants, B. diffusa was found most effective followed by $C$. aculeatum. The plants were considered virus-free when they showed absence of ICRSV in both DAC-ELISA and RT-PCR tests.
\end{abstract}

\section{Introduction}

In India, citriculture is the third largest component of the fruit industry next to mango and banana in respect of cultivated area and production. Kinnow is one of the most important citrus fruits and its cultivation is common in north India.

It is a hybrid mandarin (Citrus deliciosa) between the King Sweet Orange ( $C$. nobilis Loureiro) and Willow Leaf Mandarin (C. deliciosa Tenore) developed in 1915 by H. B. Frost at the Citrus Research Centre, Riverside, University of California, California and was released in 1935 (Frost and Krug 1942). Because of

*Author for correspondence: <drvikasbishnoi@gmail.com>. 'Jaipur National University, Jaipur-302033, Rajasthan, India. 
its vigorous growth habit, high yielding potential, large and attractive fruit size, good blend of sugars and acids and deep orange color, Kinnow has become popular among growers of the Indian subcontinent.

In recent years, loss in yield and quality of this fruit crop has been observed. Besides other factors it may be due to its susceptibility to many diseases, particularly those caused by viruses and virus like pathogens (Ahlawat 1997). Viruses such as Indian citrus ringspot virus (ICRSV), Citrustristeza virus (CTV) and citrus greening bacterium are mainly known to infect Kinnow trees and their consequences range from latent infection with little apparent effect on the host leading to its death. Up to hundred per cent incidence of ringspot disease was observed in most of the Kinnow mandarin trees in north India. The health of the infected trees deteriorates year after year and leads to yield loss between 20.54 and 98.38 per cent (Byadgi and Ahlawat 1995). Kinnow is propagated by vegetative means by grafting, therefore, use of infected budwoods acts as the main source of broadening of virus diseases. This necessitates the production of certified healthy virus-free propagation material for establishing new orchards.

The technique of in vitro shoot-tip grafting (STG) was developed by Murashige et al. (1972). Navarro et al. (1975) studied the technique in detail. Shoot-tip grafting (STG) consists grafting of in vitro generated etiolated seedling at early stage ( 2 - 3 weeks) under aseptic conditions, with a small shoot-tip (0.1 $0.2 \mathrm{~mm}$ ). Now this technique is widely adopted in citrus, peach, apple, cherry and avocado etc. to recover plants free from virus and virus-like diseases.This technique is based on the fact that the apical meristem contains little or no virus and meristematic cells grow faster than all viruses. Therefore, the production of disease-free plants by micro-grafting remains the only means to supply diseasefree bud sticks to the growers (DeLange 1978).

The roots of $B$. diffusa and leaves of $C$. aculeatum have been shown to contain potent endogenous virus inhibitory proteins called BD-SRIP and CA-SRIP, respectively (Verma and Barnwal 1999, Verma et al. 1996). These phytoproteins confer strong systemic resistance to several plants against a number of plant viruses (Verma et al. 1984, Verma et al. 1996, Gupta et al. 1999, Srivastava et al. .2004, Thakare et al. 2015). Phytoproteins isolated from B. diffusa and C. aculeatum have molecular masses of 30 and $34 \mathrm{kDa}$, respectively.

The present study was planned to eliminate ICRSV from Kinnow by using phytoproteins of Boerhaavia diffusa and Clerodendrum aculeatum with shoot-tip grafting (in vitro). 


\section{Materials and Methods}

The extraction of phytoproteins from the roots of $B$. diffusa and the leaves of $C$. aculeatum was carried out according to Verma et al. (1984). In brief, the roots of $B$. diffusa were washed, cut into small pieces, air dried at room temperature protected from the direct sunlight and ground to fine powder. The root powder (200 g) was then mixed with one litre of distilled water and shaken overnight on a shaker at $4^{\circ} \mathrm{C}$. It was then filtered through two-folds of Muslin cloth and centrifuged at $5000 \mathrm{rpm}$ for $15 \mathrm{~min}$ to obtain clear supernatant. Ammonium sulfate $[60 \%(\mathrm{w} / \mathrm{v})]$ was added to the supernatant with continuous stirring and left overnight at $4^{\circ} \mathrm{C}$. Thereafter the mixture was centrifuged at $5000 \mathrm{rpm}$ for 15 min and the supernatant was discarded. The precipitate was retained and suspended in a small amount of distilled water and then dialyzed to obtain the total protein fraction. After that, this solution was filtered with vacuum filter of pore size $0.22 \mu \mathrm{M}$ and air dried. It was used as aqueous extracts in different concentrations. Essentially a similar protocol was adopted for obtaining phytoproteins from the leaves of $C$. aculeatum.

Budsticks $(8-10 \mathrm{~cm})$ were collected from the field grown infected Kinnow plants (8 year-old) and cut into small pieces $(1-2 \mathrm{~cm})$, each containing a single or double node. They were washed under running tap water followed by treatment with $0.2 \%(\mathrm{w} / \mathrm{v})$ bavistin for $30 \mathrm{~min}$ and then washed with distilled water for removal of fungicide. Under aseptic condition in laminar air flow chamber, the nodal segments were first quickly rinsed with $70 \%$ ethanol followed by $\mathrm{HgCl}_{2} @$ $0.1 \%(\mathrm{w} / \mathrm{v})$ for ten $\mathrm{min}$ and then washed with sterilized double distilled water 3 4 times. The surface sterilized explants (nodal segments) of Kinnow were inoculated in MS fortified with BAP $(1.0 \mathrm{mg} / \mathrm{l})$, NAA $(0.25 \mathrm{mg} / \mathrm{l})$ and malt extract $(800 \mathrm{mg} / \mathrm{l})$. The different concentrations $(5,10,15$ and $20 \mathrm{mg} / \mathrm{l})$ of filter sterilized phytoproteins were added after autoclaving of themedium in aseptic condition. Explants were incubated under the controlled environment of temperature (25 \pm $2^{\circ} \mathrm{C}$ ) and light $\left(13 \mathrm{hrs} /\right.$ day illumination of 30 to $40 \mu \mathrm{mol} / \mathrm{M}^{2} / \mathrm{S}$ spectral of flux photon SFP) and 60 - 70 per cent relative humidity (RH). Three sets of 24 explants were cultured for each concentration of phytoproteins. A set of explants were cultured as control in MS containing only BAP $(1.0 \mathrm{mg} / \mathrm{l})$, NAA $(0.25 \mathrm{mg} / \mathrm{l})$ and malt extract $(800 \mathrm{mg} / \mathrm{l})$. After 30 days of incubation, healthy shoots apices of uniform size were excised and sub-cultured on freshly prepared medium that contained the same concentration of phytoproteins. After every 30 days subculturing was repeated.

The seeds from healthy fruits of $C$. jambhiri were extracted and washed thoroughly and stored in juice separately. The seeds were sterilized according to the above procedure and inoculated in MS basal medium. The culture tubes were 
incubated in BOD at temperature of $25 \pm 2^{\circ} \mathrm{C}$ in continuous darkness. These invitro raised etiolated seedlings were used as rootstock for micro-grafting.

The shoot tips with 1 - 5 leaf primordia were excised from in vitro generated shoots which were cultured in phytoproteins containing medium. An inverted " $\mathrm{T}$ " cut made on decapitated apical portion of the root stock. The flaps of cut were opened and excised shoot tip was inserted in the cortex of a triangle cut. A drop of 2,4-D (5 mg/l) was added at the triangular cut for better graft success. The micrografts were cultured in a liquid medium composed of macro- and microelements of MS fortified with the vitamins of White's medium (1943) and sucrose @ 6.0 per cent. A folded Whatman No. 4 filter paper platform (perforated in centre) was placed for the vertical standing of the rootstock. The micrografts were kept at $25 \pm 2{ }^{\circ} \mathrm{C}$ in continuous dark for $24 \mathrm{hrs}$ and there after exposed daily to 13 : $11 \mathrm{hrs}$ photoperiod. Eight to ten weeks after grafting, successful micrografts were then kept in half strength of MS supplemented with NAA and IBA (each at $0.5 \mathrm{mg} / \mathrm{l}$ ) to ensure better rooting.

These micrografts were carefully taken out and embedded overnight in cotton in tray which contained half strength MS salt solution. Then transferred in pots containing steam sterilized soil + perlite + vermiculite in $1: 1: 1$ ratio and capped in poly house at $90 \%$ humidity $26 \pm 2^{\circ} \mathrm{C}$. The humidity was lowered with passage of time i.e. at 10 - 12 weeks up to $60 \%$. Plantlets were irrigated with Hoagland's solution at 3 days interval for the period of one month. Later these were irrigated with Hoagland's solution and simple water alternately at 3 days interval. After this, the pots were transferred to green house for next 6 months. The leaf samples were taken from different concentration of phytoproteins and tested for ICRSV by DAC-ELISA. Further confirmation was done by RT-PCR (Prabha and Baranwal 2011). Virus-free plants were multiplied and maintained in the polythene house.

Data acquired from the experiments was statistically analyzed with MATLAB 13 for windows 7 Ultimate version for linear model/general factorial. To evaluation homogenous subsets for various treatments, post hoc test/Tukey's honesty significant difference (HSD) at a level of significance of $\alpha=0.05$ was applied.

\section{Results and Discussion}

Data regarding the effects of phytoproteins of $B$. diffusa and C. aculeatumon shoot proliferation and growth of regenerated shoots of Kinnow mandarin are given in Tables 1 and 2. The data were recorded after 30 days of inoculation of the nodal explants and 25 days after culturing of shoots taken from the nodal explants and 25 days after first sub-culturing. 
Table 1. The effect of different concentrations of phytoproteins of B. diffusa on in vitro growth and proliferation of nodal explants of Kinnow. Phytoproteins were added to MS supplemented with $1 \mathrm{mg} / 1 \mathrm{BAP}, 0.25 \mathrm{mg} / 1 \mathrm{NAA}$ and $800 \mathrm{mg} / \mathrm{l} \mathrm{ME}$.

\begin{tabular}{|c|c|c|c|}
\hline \multirow{2}{*}{$\begin{array}{l}\text { Conc. } \\
(\mathrm{mg} / \mathrm{l})\end{array}$} & \multirow{2}{*}{$\begin{array}{l}\text { Thirty days after the } \\
\text { culture of explants } \\
\text { Length of the main } \\
\text { shoot (in mm) }\end{array}$} & \multicolumn{2}{|c|}{$\begin{array}{l}\text { Twenty five days after } \\
\text { sub-culturing }\end{array}$} \\
\hline & & $\begin{array}{l}\text { Length of the main } \\
\text { shoot (in mm) }\end{array}$ & $\begin{array}{l}\text { Number of } \\
\text { Offshoots }\end{array}$ \\
\hline 0 & $4.37 \pm 0.0882^{\mathrm{a}}$ & $8.38 \pm 0.0939^{a}$ & $5.57 \pm 0.1129^{a}$ \\
\hline 5 & $4.90 \pm 0.1152^{\mathrm{bc}}$ & $8.89 \pm 0.1157 \mathrm{bc}$ & $7.12 \pm 0.0784^{\mathrm{ab}}$ \\
\hline 10 & $5.53 \pm 0.0882^{\mathrm{bcd}}$ & $12.44 \pm 0.0762^{\mathrm{cd}}$ & $9.67 \pm 0.3064^{b c}$ \\
\hline 15 & $6.13 \pm 0.0882^{\text {cde }}$ & $15.83 \pm 0.0657^{\mathrm{bcd}}$ & $13.14 \pm 0.2395^{\mathrm{cd}}$ \\
\hline 20 & $5.43 \pm 0.0882^{e}$ & $11.80 \pm 0.1342^{e}$ & $7.67 \pm 0.1202^{\mathrm{e}}$ \\
\hline
\end{tabular}

Phytoproteins of $B$. diffusaat $20 \mathrm{mg} / \mathrm{l}$ concentration were found to produce cytotoxic effects such as necrosis of nodal explants causing their death. Data shown are mean \pm SEM of three experiments, each consisting of 24 replicates. Means followed by the same letter/s are significantly different from each other (general factorial/Tukey's HSD at $\alpha=0.05$ ).

Table 2. The effect of different concentrations of phytoproteins of C. aculeatum on in vitro growth and proliferation of nodal explants of Kinnow. Phytoproteins were added to MS supplemented with $1 \mathrm{mg} / 1 \mathrm{BAP}, 0.25 \mathrm{mg} / 1 \mathrm{NAA}$ and $800 \mathrm{mg} / \mathrm{l} \mathrm{ME}$.

\begin{tabular}{|c|c|c|c|}
\hline \multirow{2}{*}{$\begin{array}{l}\text { Conc. } \\
(\mathrm{mg} / \mathrm{l})\end{array}$} & \multirow{2}{*}{$\begin{array}{l}\text { Thirty days after the } \\
\text { culture of explants } \\
\begin{array}{c}\text { Length of the main shoot } \\
(\mathrm{mm})\end{array}\end{array}$} & \multicolumn{2}{|c|}{$\begin{array}{c}\text { Twenty five days after } \\
\text { sub-culturing }\end{array}$} \\
\hline & & $\begin{array}{l}\text { Length of main } \\
\text { shoot (mm) }\end{array}$ & $\begin{array}{l}\text { Number of } \\
\text { offshoots }\end{array}$ \\
\hline 0 & $4.37 \pm 0.0882^{\mathrm{a}}$ & $8.38 \pm 0.0939^{a}$ & $5.57 \pm 0.1129^{a}$ \\
\hline 5 & $4.74 \pm 0.1272^{b}$ & $9.17 \pm 0.1488^{b}$ & $6.58 \pm 0.0643^{\mathrm{bcd}}$ \\
\hline 10 & $5.44 \pm 0.1868^{c}$ & $11.78 \pm 0.0696^{\mathrm{cd}}$ & $7.81 \pm 0.1419^{c d}$ \\
\hline 15 & $5.93 \pm 0.0933^{\mathrm{d}}$ & $14.28 \pm 0.0889^{d}$ & $10.70 \pm 0.2504^{\mathrm{d}}$ \\
\hline 20 & $5.47 \pm 0.0722^{\mathrm{e}}$ & $9.78 \pm 0.1660^{e}$ & $8.53 \pm 0.2206^{\mathrm{e}}$ \\
\hline
\end{tabular}

The phytoproteins of C. aculeatum at $\{20 \mathrm{mg} / \mathrm{l})$ was found to produce cytotoxic effects such as necrosis of nodal explants leading to their death. Data shown are mean \pm SEM of three experiments; each experiment consisting of 24 replicates. Means followed by the same letter/s are significantly different from each other (general factorial/Tukey's HSD at $\alpha=0.05$ ).

It was noted that the phytoproteins occurring in B. diffusa and C. aculeatum were found to produce beneficial effect on the growth of offshoots as well as their proliferation. However, the phytoproteins from B. diffusa were more 
effective than those from $C$. aculeatum. The growth and proliferation of shoots progressively improved with the increase in the concentrations of the phytoproteins $(05,10$ and $15 \mathrm{mg} / \mathrm{l})$. In C. aculeatum and B. diffusa concentration of $20 \mathrm{mg} / \mathrm{l}$ proved deleterious to plant growth. Furthermore, the beneficial effects of phytoproteins from both sets of plants showed a cumulative beneficial effect during subcultures, which was more prominent when the first subculture was done.
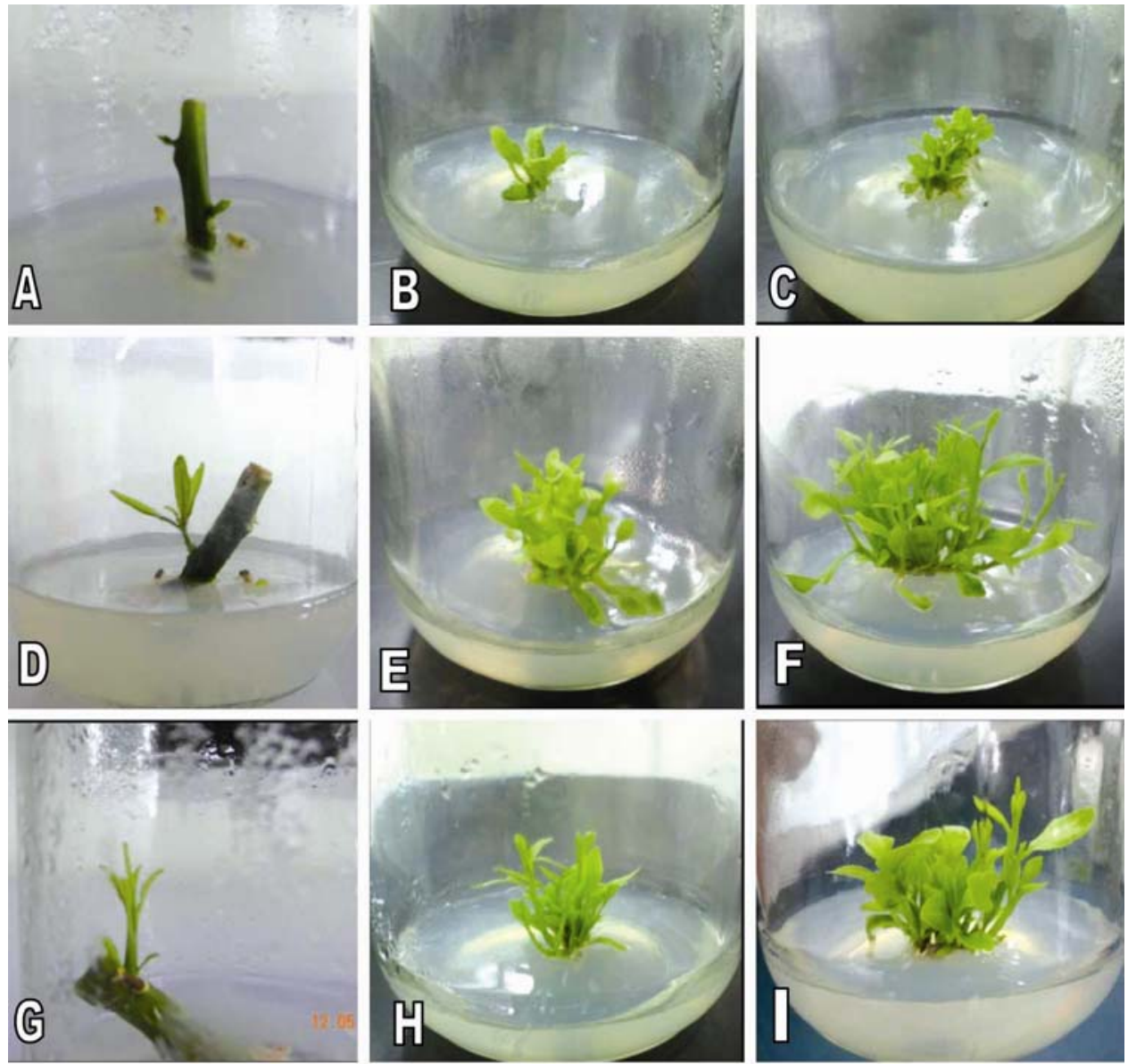

Fig. 1. Showing the effect of most efficacious concentrations of phytoproteins obtained from the leaves of B. diffusa (D-F) and the roots of C. aculeatum (G-I) on explant growth and shoot proliferation (A-C: control).

In all cases, the growth and proliferation of the shoots were remarkably far more pronounced as compared to the control. The effects of phytoproteins from B. diffusa on growth and proliferation of shoots were spectacular. 
Phytoproteins from B. diffusa and C. aculeatum were beneficial for growth and proliferation of isolated shoots of Kinnow mandarin. The role of phytoproteins was neither purely nutritional nor hormonal. While the growth and proliferation of shoots improved in their respective optimum concentrations up to two subcultures and their beneficial effects were carried forward in the subsequent subcultures even in their absence. On the contrary, their presence in the medium beyond two subculture was deleterious for both growth and proliferation of shoots.

It is interesting to note that the phytoproteins from B. diffusa as well as $C$. aculeatum had an additive effect in further promoting the growth and proliferation of isolated shoots of Kinnow over that already obtained in the optimum treatments containing cytokin in and auxins along with other nutrients and growth promoting substances, including vitamins, amino acid and sucrose. If it were only nutritional role of phytoproteins in the medium then the growth and proliferation of shoots should have been promoted in the continuous presence of the phytoproteins from $B$. diffusa and $C$. aculeatum in the medium at their optimum concentration of 15 or $10 \mathrm{mg} / \mathrm{l}$ but it was not shown to be so, since their presence in the nutrient medium beyond two subcultures became deleterious for the growth and proliferation of excised shoots. The results were similar to the observations reported by Singh 2006.

The shoots nurtured in the presence of phytoproteins did require compulsory cytokinin and auxin in the medium. Thus, the phytoproteins did not substitute for growth hormones. However, at the same time the phytoproteins showed their carry-forward effect on growth and proliferation which is closely similar to action of growth hormones.
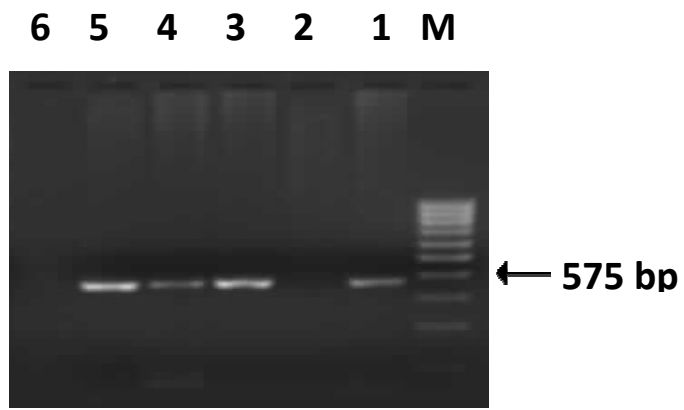

Fig. 2. Agarose gel electrophoresis of Kinnow plants raised from in vitro phytotherapy coupled with STG employing various concentrations of phytoproteins obtained from C. aculeatum. Lane $\mathrm{M}$ is $1 \mathrm{~kb}$ DNA ladder, lane 1 and 2 are positive and negative controls, respectively; lane 3 to 5 correspond to the products obtained from Kinnow plants raised at 5, 10 and $15 \%(\mathrm{v} / \mathrm{v})$ concentration of phytoproteins, showing the presence of ICRSV. Lane 6, where no amplification was observed, corresponds to the Kinnow plants raised at $20 \%$ concentration of C. aculeatum phytoproteins, respectively. 
The carry-forward effects of phytoproteins observed in the present investigation in respect of growth and proliferation of shoot is parallel to resistance to viral infection when shoot-tips (in shoot-tip grafting) were taken from these excised shoots from phytoproteins containing medium. The plants raised from shoot-tip grafting coupled with phytotherapy were free from ICRSV (Table 3).

Table 3. Effect of phytoproteins on grafting success and elimination of ICRSV.

\begin{tabular}{cccc}
\hline \multirow{2}{*}{$\begin{array}{c}\text { Conc. } \\
(\mathrm{mg} / \mathrm{l})\end{array}$} & $\begin{array}{c}\text { Per cent grafting } \\
\text { success rate }\end{array}$ & \multicolumn{2}{c}{ Per cent virus elimination } \\
\cline { 3 - 4 } Boerhaavia diffusa & DAC-ELISA & RT-PCR \\
\hline $\begin{array}{c}\text { Control } \\
5\end{array}$ & $58.36 \pm 2.4365^{\mathrm{a}}$ & 0.00 & 0.00 \\
10 & $47.22 \pm 1.3900^{\mathrm{bc}}$ & 8.82 & 0.00 \\
15 & $33.33 \pm 2.4076^{\mathrm{bc}}$ & 25.00 & 12.50 \\
$\mathbf{2 0}$ & $20.83 \pm 2.4047^{\mathrm{d}}$ & 46.67 & 33.33 \\
Clerodendrum & $\mathbf{1 1 . 1 1} \pm \mathbf{1 . 3 9 0 0 ^ { \mathrm { e } }}$ & $\mathbf{6 2 . 5}$ & $\mathbf{4 0 . 0 0}$ \\
Control & $58.36 \pm 2.4365^{\mathrm{a}}$ & & \\
5 & $43.05 \pm 1.3867^{\mathrm{ab}}$ & & \\
10 & $30.55 \pm 1.3900^{\mathrm{bc}}$ & 3.00 & 0.00 \\
15 & $19.44 \pm 1.3867^{\mathrm{cd}}$ & 50.00 & 0.00 \\
$\mathbf{2 0}$ & $\mathbf{1 3 . 8 9} \pm \mathbf{1 . 3 9 0 0 ^ { \mathrm { e } }}$ & $\mathbf{7 0 . 0 0}$ & 20.00 \\
\hline
\end{tabular}

Data shown are mean \pm SEM of three experiments; each experiment consisted of 24 replicates. Means followed by the same letter/s are significantly different from each other (general factorial/Tukey's HSD at $\alpha$ 0.05).

The percentage of successful grafts depended on the size of the shoot-tip. Increase in the size of the shoot tip also increased percentage of successful grafts. Different sizes of shoot-tips $(0.3-0.8 \mathrm{~mm})$ were grafted on in vitro raised $C$. jambhiri seedlings. Maximum micrograft success rate (58.36\%) was observed with the $0.6 \mathrm{~mm}$ size. Decrease in the per cent micrograft success rate was observed when increasing or decreasing the size of the shoot tip from $0.6 \mathrm{~mm}$. Size of the scion had been shown to have a noteworthy effect on micrograft success, with higher survival rate with larger scion size and lower with smaller scion size (Navarro 1988, Thimmappaiah et al. 2002, Suarez 2005, Sanabam et al. 2015). In the present study, by combining shoot-tip grafting with phytotherapy, it was possible to use large-sized shoot-tips $(0.6 \mathrm{~mm})$ that gave a reasonable degree of grafting success without transferring virus through grafting. The advantages of 
using large shoot-tip sizein shoot-tip grafting included improved micro-bud uptake, speeding up the process and higher success rate for less skilled technicians.

The effect of phytoproteins coupled with shoot-tip grafting is presented in Table 3. Considering the factors of per cent grafting success rate and per cent virus elimination, the best antiviral effect ( $50 \%$ virus elimination) was observed with C. aculeatum at $20 \mathrm{mg} / \mathrm{l}$ with $13.89 \%$ grafting success followed by $B$. diffusa ( $40 \%$ virus elimination) at $20 \mathrm{mg} / \mathrm{l}$ concentration with $11.11 \%$ grafting success rate. When concentrations of phytoproteins were increased, percentage of virus elimination was also increased but the per cent grafting success rate was decreased. Higher concentration of phytoproteins had negative effect on grafting success rate.

Since ICRSV has no vector for transmission, shoot-tip grafting strategy for management of the disease would be the better option. Phytotherapy has been coupled with shoot-tip grafting for best results. During these investigations, therefore the ICRSV-free plant material of the Kinnow has been developed Sharma et al. 2007.

Effect of these phytoproteins on virus resistance capability and vegetative growth of cultured tissue was also seen by Verma et al. 1998, Gupta 1999, Srivastava 1999 and Thakare et al. 2015. Phytoproteins from C. aculeatum, B. diffusa and many other plant spp. have useful role to play in enhancing growth as well as virus elimination in certain plants. In this way it may be possible to produce virus-free plants without resorting to preying somatic hybridization or transgenosis. In any case, such studies provide ample scope for further investigations which can be utilized for improvement of plant spp. to increase the useful products from them, be their fruit yield or active principles.

Phytoproteins extracted from B. Diffusa roots and C. aculeatum leaves were incorporated with shoot-tip grafting of Kinnow. Shoots from infected Kinnow plants were cultured in vitro in the presence of different concentrations of these phytoproteins in the medium. Shoot tips were taken from these in vitro generated explants and grafted in vitro on C. jambhiri. Phytoproteins were not only found to eliminate ICRSV in in vitro generated Kinnow plants but also they enhanced the growth and proliferation of Kinnow explants when cultured in phytoproteins containing the medium.

\section{Acknowledgement}

The authors are grateful to Dr. V K Baranwal, Head, the Virology unit, Department of Plant Pathology, Indian Agriculture Research Institute, Pusa, New Delhi for helping in indexing of virus through DAC- ELISA and RT-PCR. 


\section{References}

Ahlawat YS (1997) Viruses greening bacterium and viroids associated with citrus (Citrus species) decline in India. J. Agril. 67(2): 51-57.

Byadgi AS and Ahlawat YS (1995) A new viral ringspot disease of citrus (Citrus species) in India. J. Agril. Sci. 65(10): 763-70.

DeLange JH (1978) Shoot-tip grafting, a modified procedure. Citrus and Subtropical Fruits Journal 539: 13-15.

Frost HB and Krug CA (1942) Diploid-tetraploid periclinal chimeras as bud variation in citrus. Genetics 27: 619-34.

Gupta RK, Srivastava A and Verma HN (2004) Callus culture and organogenesis in Boerhaavia diffusa. A potent antiviral protein containing plant. Physiol. Mol. Bio. Plant 10: 263-268.

Gupta RK (1999) Micropropagation of B. diffusa for producing the systemic resistance inducing protein (SRIP) for viral disease management. Ph.D. Thesis, Lucknow University, Lucknow, India.

Murashige T, Bitters WP, Rangan TS, Nauer EM, Roistacher CN and Holliday PB (1972) A technique of shoot apex grafting and its utilization towards recovering virus-free citrus clones. Hort.Sci. 7: 118-19.

Navarro L (1988) Application of shoot-tip grafting in vitro to woody species. Acta Hort. 227: 43-45.

Navarro L, Roistacher CN and Murashige T (1975) Improvement of shoot tip grafting in vitro for virus-free citrus. J. Amer. Soc. Hort. Sci. 100: 471-79.

Prabha K and Baranwal VK (2011) Indian citrus ringspot virus: localization of virus in seed tissues and evidence for lack of seed transmission. Phytoparasitica 39(5): 491-496.

Sanabam R, Singh NS, Handique PJ and Devi HS (2015) Disease-free khasi mandarin (Citrus reticulate Blanco) production using in vitro microshoot tip grafting and its assessment using DAS-ELISA and RT-PCR. Scientia Horticulturae 189: 208-213.

Sharma S, Singh B, Rani R, Zaidi AA, Hallan V, Nagpal A and Virk GS (2007) In vitro production of Indian citrus ringspot virus (ICRSV) free kinnow plants employing phytotherapy coupled with shoot tip grafting. In Vitro Cell Dev. Biol. Plant 43: 254259.

Shrivastava A (1999) Micro-propagation of Clerodendrum aculeatum and isolation of virus inhibitory substance from culture cells inducing systemic resistance in susceptible host. Ph.D. Thesis, Lucknow University, Lucknow.

Singh AK (2006) Comparative studies on control of certain ailments of plants, mice and cancer cell lines and in vitro stimulation of growth of plants and virus resistance using phytoproteins from Boerhaavia diffusa and Clerodendrum aculeatum. Ph.D. Thesis. Lucknow University, Lucknow, India.

Srivastava A, Gupta RK and Verma HN (2004) Micropropagation of Clerodendrum aculeatum through adventitious shoot induction and production of consistent amount of virus resistance inducing protein. Indian J. Exp. Biol. 42: 1200-1207. 
Suarez IE, Schnell RA, Kuhn DN and Litz RE (2005) Micrografting of ASBVd-infected Avocado (Persea Americana) plants. Plant Cell Tiss. Org. Cult. 80: 179-185.

Thakare R, Rathod D and Rai M (2015) Role of medicinal plants and their metabolites for the management of plant pathogens. Sustainable crop disease management using natural products. pp. 131-143.

Thimmappaiah P, Puthra GT and Anil SR (2002) In vitro grafting of cashew (Anacardium occidentale L.). Sci. Horti. 92: 177-182.

Verma HN and Barnwal VK (1999) Antiviral phytoproteins as biocontrol agents for efficient management of plant virus disease. In: Biocontrol potential and their exploitation in corp pest and diseases management (Eds. R.L. Rajak and Rajeev K. Upadhyay). Aditya Book Pvt. Ltd. New Delhi. pp. 7-79.

Verma HN, Baranwal VK and Srivastava S (1998) Antiviral substances of plant origin. In: Plant virus disease control, edited by A Hadidi, RK Khetarpal, A Kozenzava (American Phytopathological Socity (APS) Press, St. Paul, Minnesota). pp. 154-162.

Verma HN, Chowdhery B and Rastogi P (1984) Antiviral activity of different Clerodendrum L. species. Z Pflanzenkar Pflenzenschutz 91: 34-41. 